\title{
Soldadinhos-de-Chumbo e Bonecas: Representações Sociais do Masculino e Feminino em Jornais de Empresas
}

\author{
Alessandra Morgado Horta Corrêa \\ Maria Cecília Lemos Gontijo \\ Lílian Bambirra de Assis \\ Alexandre de Pádua Carrieri \\ Marlene Catarina de Oliveira Lopes Melo
}

\begin{abstract}
ResUmo
Por meio deste trabalho, buscou-se retratar aspectos das representações de gênero socialmente construídas nos jornais de circulação interna de duas empresas localizadas em Minas Gerais, sendo uma com o setor operacional predominantemente masculino e a outra, com maioria feminina. Para tanto, (re)visitaram-se os conceitos teóricos das representações sociais, da mídia nas representações sociais e da reprodução dos papéis sociais e culturais do homem e da mulher. Compreende-se que as representações sociais são um complemento importante para os estudos organizacionais, ao possibilitar uma análise das interações dos atores, que influenciam a dinâmica e os resultados da organização. Essas relações foram entendidas por meio da linha editorial, diagramação e linguagem dos jornais internos, que, juntamente com a utilização de elementos da Análise do Discurso, permitiram levantar os seguintes temas: 'assuntos femininos', 'assuntos masculinos', 'relações de poder' e 'competitividade', que se relacionam às representações sociais de gêneros. Verificou-se que os jornais internos analisados auxiliaram na disseminação do discurso da alta gerência.
\end{abstract}

Palavras-chave: representações sociais; mídia; relações de gênero; relações de poder; competitividade.

\begin{abstract}
This article presents aspects of the genders social representations in the newsletters of two factories located in the state of Minas Gerais, Brazil, one of which being predominantly male and the other female shopfloor. In order to proved with the investigation, the theoretical concepts of both social and media representations as well as reproduction of social and cultural roles of woman and man were revisited. It has been understood that the social representations are important to the organizational studies once they permit an analysis of the actors who influence both the dynamic and the results of the organization. These relations were observed in the newsletters' editorial line, lay out and in the language used on its publication which with some elements of discourse analysis allowed the finding of these subjects in the newsletters: female subjects, male subjects, power relations and competitiveness which related to the genders social representations. In the end, it was possible to verify that these analyzed company newsletters helped the upper management to disseminate its discourse.
\end{abstract}

Key words: social representations; media, gender relations; power relations; competitiveness. 


\section{INTRODUÇÃO}

A Administração vem recorrendo a outras áreas do conhecimento para integrar os estudos organizacionais, que se têm mostrado cada vez mais complexos e diversificados. Neste sentido, as representações sociais têm contribuído especialmente para o entendimento da cultura e das abordagens de gênero presentes nas empresas, o que possibilita uma reflexão e (re)leitura do ambiente organizacional, uma vez que têm como importante difusor a mídia, que reproduz as relações sociais. Segundo observaram Wood Júnior e Paula (2002), por meio da linguagem e dos símbolos que permeiam os textos, emergem elementos que são relevantes para a construção do discurso que sustenta realidades organizacionais.

Neste contexto, o estudo proposto neste artigo (re)visita os conceitos teóricos da mídia e das relações de gênero na reprodução dos papéis sociais e culturais para avaliar como as representações sociais de gênero podem ser reproduzidas em jornais internos de circulação por toda a empresa.

Para a concretização dessa pesquisa documental de representações sociais de gênero, foram analisados jornais internos de duas empresas localizadas em Minas Gerais, denominadas como 'Marte', com mão-de-obra predominantemente masculina, e 'Vênus', com setor operacional basicamente feminino. Os dados foram analisados por meio da linha editorial, diagramação e linguagem dos jornais internos e pela utilização de elementos da Análise do Discurso (AD), com destaque para os temas recorrentes no discurso dos jornais e três estratégias de persuasão, segundo a abordagem de Faria e Linhares (1993): construção das personagens, seleção lexical e relações entre os conteúdos explícitos e os implícitos.

Na análise foram levantados os seguintes temas nos jornais: 'assuntos femininos', 'assuntos masculinos', 'relações de poder'e 'competitividade', o que possibilitou verificar que o discurso da alta administração, disseminado nos jornais pesquisados, tentou refletir a vida cotidiana, o trabalho, a economia doméstica e as relações sociais entre homens e mulheres.

\section{Sociologia, Psicologia Social e Antropologia: Entendendo as Representações Sociais}

Observa-se que a noção de representação social se encontra permeada tanto nos domínios da Sociologia, da Psicologia Social como também da Antropologia 
Social, pois ora existe um pensar que defende a supremacia do social sobre o individual, ora, ao contrário, em outros momentos, existe uma predominância do individual sobre o social (Cavedon, 2003).

A expressão 'representação social' remete ao sociólogo Emile Durkheim, tendo ficado por um longo período esquecida, retornando apenas na década de 1950 com Serge Moscovici ao desenvolver uma teoria sobre representações sociais no campo da Psicologia Social (Alexandre, 2001).

Primeiramente, no campo da Sociologia, a noção sobre representação é apresentada por Durkheim de forma a separar o individual do social, uma vez que as representações individuais não conseguem sobrepujar as representações coletivas. Assim, as representações que exprimem a sociedade expõem características próprias e conteúdo totalmente diferente das representações individuais (Durkheim ${ }^{(1)}$ como citado em Cavedon, 2003).

Já nos domínios da Psicologia Social e remetendo a Moscovici (1978), entendese que as representações sociais circulam por meio de fala, gesto, ou encontro no universo cotidiano, ou mesmo atuam por meio de observações e análises, bem como interpretações dessas mesmas observações. Essas representações sociais se apresentam como forma de guiar o comportamento, dando-lhe sentido e uma como forma de remodelar e reconstituir os elementos do meio ambiente em que este comportamento se insere. Assim, a representação social pode ser apreendida como o posicionamento da consciência subjetiva nos espaços sociais, com o intuito de construir percepções por parte dos indivíduos (Moscovici, 1978).

Assim, dentro dos campos da Psicologia Social, Moscovici (1978) procura dar ênfase por igual tanto ao social como ao individual. Para Cavedon (2003), de acordo com esta vertente, deve-se considerar tanto os comportamentos individuais, como os fatos sociais em sua concretude e especificidade histórica, ou seja, o social também assume papel relevante no processo de construção das representações sociais.

Considerando também uma dimensão antropológica, observa-se, de acordo com Magnani (1986) que, mesmo apresentando complexidade em sua definição, as representações são apreendidas como uma espécie de imagem mental da realidade, composta por experiências individuais decorrentes da realidade social em que o ator está imerso. Esta realidade seria constituída por elementos como família, rede de vizinhança, bairro, categoria profissional, partido e classe social, entre outros. Magnani (1986) salienta que as representações são formadas pelas condições sociais de inserção dos diversos agentes, sendo que sua manifestação se dá pelo discurso, em processo de contínua reconstituição. Além disso, a autora também chama a atenção para o fato de que, juntamente com a análise dos 
discursos, deve-se ter a análise da prática, pois discurso e prática não são realidades que se opõem, mas constituem pistas diferentes e complementares para a compreensão mais clara do significado.

Cavedon (2003) observa que os discursos das representações no campo tanto da Psicologia Social quanto da Antropologia Social se aproximam, quando eles declamam a complementaridade entre o individual e o social. Tal fato, para a autora, aponta o repensar das fronteiras entre as diferentes áreas do conhecimento.

A representação social pode ser entendida como sendo:

fruto do sociocultural, esferas que se interligam através dos significados partilhados. Reconhece-se a existência da subjetividade, mas ela só se constrói e se consolida mediante as relações que se estabelecem entre os diferentes atores sociais que compõem um determinado grupo, isto porque existe uma significação construída, que lhes é comum (Cavedon, 2003, p. 102).

Minayo (1995) reconhece a importância das representações sociais nas Ciências Sociais e as conceitua como categorias de pensamento que reproduzem a realidade, explicando-a, justificando-a e questionando-a. Acrescenta-se ainda, de acordo com Pontes, Naujorks e Sherer (2001), que o estudo das representações sociais deve ser remetido a um panorama multifacetado em que está submersa a vida social, com todos os seus matizes, permitindo que temas relacionados à desigualdade social, preconceito e exclusão venham à tona.

As representações sociais aparecem por meio das palavras, sentimentos e condutas, devendo ser estudadas a partir das estruturas e comportamentos sociais. Elas podem ser encontradas na comunicação e nas práticas sociais, seja no diálogo, discurso, ritual, arte, padrão de trabalho e produção. As representações de cada indivíduo refletem o grupo social a que ele pertence, que se justifica conforme seus interesses específicos (Jovchelovitch, 1995; Minayo, 1995).

Jovchelovitch (1995) informa que o objetivo das representações sociais não é abandonar o indivíduo, mas reconhecer o social em sua totalidade, não sendo esta formada por um agregado de indivíduos. A análise das representações sociais transcende os processos normais de comunicação e vida, buscando as diferenças que os tornam peculiares, que são denominados de processos de mediação social. "Assim, são as mediações sociais, em suas mais variadas formas, que geram as representações sociais" (Jovchelovitch, 1995, p. 81). Nesta discussão, as representações sociais são apreendidas como:

[...] uma estratégia desenvolvida por atores sociais para enfrentar a diversidade

e a mobilidade de um modo que, embora pertença a todos, transcende cada um 
individualmente. ..., elas não apenas surgem através de mediações sociais, mas tornam-se, elas próprias, mediações sociais. E enquanto mediação social, elas expressam por excelência o espaço do sujeito na relação com a alteridade, lutando para interpretar, entender e construir o mundo (Jovchelovitch, 1995, p. 81).

De forma geral, o que se observa é que "as representações sociais estão associadas às práticas culturais, reunindo tanto o peso da história e da tradição, como a flexibilidade da realidade contemporânea" (Alexandre, 2001, p. 123). Ao trabalhar as representações sociais, busca-se a relação existente em línguadiscurso-ideologia, concebendo a comunicação como um complexo processo de formação de sujeitos e produção de sentidos, processos de argumentação, subjetivação e construção da realidade (Pontes, Naujorks, \& Sherer, 2001).

Conforme observa Hall (2002), o indivíduo altera sua identidade de acordo com a forma em que é interpelado ou representado. Uma destas formas de articulação seria a mídia que, conforme acrescenta Thompson (1995), serve para reestruturar relações sociais existentes e, conseqüentemente, as instituições e organizações de que elas fazem parte.

\section{As Representações Sociais na Mídia}

Observa-se que as indústrias da mídia, ao difundirem e produzirem mensagens para a sociedade, assumem papel fundamental no comportamento e na formação do indivíduo. Os meios de comunicação envolvem e 'bombardeiam' os indivíduos com grande quantidade de informações que, por meio de imagens e sons, tentam criar, mudar e até mesmo cristalizar atitudes e opiniões (Alexandre, 2001).

Para Pontes, Naujorks e Sherer (2001), os meios de comunicação são percebidos como componentes e alicerces culturais e ideológicos. Em uma sociedade globalizante, o sujeito participa da vida social de acordo com o volume e qualidade de informações que detém, mas paradoxalmente, as denominadas "culturas de massa" servem como monopolizadoras do saber, respaldadas em um regime de verdade que oferece uma ilusória transparência social em que todos se comunicam com todos.

Adorno (1975, p. 292) se refere à indústria cultural em oposição à denominada cultura de massa, destacando a ideologia como ponto central e os representantes da indústria cultural que "[...] pretendem que essa indústria forneça aos homens, num mundo pretensamente caótico, algo como critérios para sua orientação, e que só por esse fato ela já seria aceitável". Assim, as idéias de ordem que ela desenvolve são sempre as do statu quo. A ordem imperativa da indústria cultural nada tem em 
comum com a liberdade e sim com a submissão em virtude de seu poder. A difusão da ideologia faz com que a consciência crítica seja substituída pelo conformismo, já que " [...] impede a formação de indivíduos autônomos, independentes, capazes de julgar e de decidir conscientemente..., condição prévia de uma sociedade democrática, que não poderia salvaguardar e desabrochar senão através de homens não tutelados" (Adorno, 1975, p. 295). Para o autor, a frustração das pessoas propiciada pela indústria cultural, ao afirmar a perfeita ordenação social, não é suplantada porque aquela reorienta as massas, produzindo modelos de comportamento.

Tem-se, na visão crítica de Thompson (1995, p. 288), que a comunicação de massa é a "produção institucionalizada e a difusão generalizada de bens simbólicos através da transmissão e do armazenamento da informação/comunicação". A comunicação, especialmente a de massa, pode apresentar aspectos positivos por ser democrática, proporcionar diversão e dispor de uma riqueza de informação; e pontos negativos por ser, em alguns casos, conservadora, ao trabalhar apenas com o que já foi assimilado, conformista e encorajadora de uma visão passiva e acrítica da sociedade, valorizando em demasia a informação da atualidade, entorpecendo a consciência histórica e difundindo uma cultura homogênea (Alexandre, 2001). Neste sentido, Pontes, Naujorks e Sherer (2001) apreendem que as mídias não devem ser vistas apenas como recursos audiovisuais, mas também devem representar importante componente ao complexo conjunto da comunicação educacional com vistas a colaborar na formação dos cidadãos.

É neste contexto que vale a pena discutir como o pensamento dos indivíduos se enraíza no social e analisar também os processos constitutivos das representações sociais e sua influência no comportamento dos indivíduos. Os meios de comunicação, em especial o de massa, apresentam relevância justamente porque:

se tornam instrumentos fundamentais na produção da nova coesão social, exatamente porque lidam com a fabricação, reprodução e disseminação de representações sociais que fundamentam a própria compreensão que os grupos sociais têm de si mesmos e dos outros, isto é, a visão social e a auto-imagem (Alexandre, 2001, p.116).

Guareschi (1989, p. 9) complementa, ressaltando ainda que:

a comunicação "elabora" o nosso cotidiano, legitima o nosso cotidiano, justifica e transforma, se necessário, o nosso cotidiano. Assim como, para viver, você precisa de arroz, feijão, carne e de outros alimentos, para "sobreviver" na sociedade, você precisa de família, escola, religião, trabalho, meios de comunicação, política... Mas o arroz você não o come cru. Alguém deve preparálo, cozinhá-lo, temperá-lo. É exatamente isso o que acontece também, com as instituições sociais (família, trabalho, etc.): alguém precisa "cozinhá-las", 
"temperá-las"; é isso que eu chamo de "elaborar". E quem faz isso é a comunicação silenciosa, indireta, subjacente... mas tremendamente eficaz! Pois sem isso a sociedade seria diferente.

Nesta discussão, Silva (1999, p. 2) esclarece que "a publicidade reflete a forma como os padrões estabelecidos socialmente estão instaurados. Afinal, não é função da publicidade criar conflitos sociais, mas sim vender produtos cada vez a um número maior de pessoas". A comunicação, sob a perspectiva da representação social, pode ser entendida, de acordo com Alexandre (2001, p.118), como: "o fenômeno pelo qual uma pessoa influencia ou esclarece outra que, por sua vez, pode fazer o mesmo em relação à primeira. Seus elementos básicos são o emissor, o receptor, a mensagem, o código e o veículo". A análise do comportamento aplica-se às fontes e aos receptores, que podem ser trabalhados na perspectiva das representações sociais por ligar e relacionar os fatores pessoal e social de um processo.

No bojo desta questão, a linguagem apresenta importante papel por ter dimensão tanto emotiva como também cognitiva. Para Alexandre (2001, p.120) "cada palavra, por mais descritiva que pretenda ser, contém uma carga de emoção". Além disso, observa-se que hoje em dia o parecer vale mais do que o ser e a preocupação passa a ser não mais com o que é comunicado, mas sim com a maneira com que se comunica e com o significado que a comunicação tem para o ser humano (Alexandre, 2001, grifo do autor). Assim, a mídia reforça as representações sociais, fazendo com que os grupos obtenham reconhecimento e visibilidade como forma de afirmação de sua identidade social (Cappelle, Mageste, Melo, \& Brito, 2003), evidenciando, desta forma, os papéis socialmente construídos para homens e mulheres.

\section{Mídia, Representações Sociais e Relações de Genero nas Organizações}

Autores como Cramer, Paula Neto e Silva (2002) observam que as relações entre os gêneros devem ser analisadas como processos simbólicos socialmente construídos. Conforme aponta Meyer (1998), considerando que homens e mulheres são categorias socialmente construídas, a realidade em que se inserem é produzida na linguagem e pela linguagem em complexo jogo de poder. $\mathrm{O}$ discurso, que descreve ou informa, está construindo tanto o social como os sujeitos nele implicados. Os meios de comunicação explicitam as desigualdades sociais e as informações veiculadas estão carregadas de preconceitos, mostrando que homens e mulheres possuem lugares preestabelecidos na sociedade. Como não é papel 
da mídia gerar conflitos, observam-se os padrões sociais para reproduzir e não questionar (Silva, 1998).

Trazendo as relações sociais para a mídia, Baudrillard (1995) reconhece dois modelos diferenciados: o masculino e o feminino. O modelo masculino está centrado na exigência e na escolha. $\mathrm{O}$ homem não tolera fracasso, ratifica a intransigência, a decisão e a energia como virtude competitiva. Já o modelo feminino está pautado na necessidade da mulher em comprazer a si própria. "No fundo, continua-se a convidar os homens a brincar de soldadinho e as mulheres a servirem de bonecas consigo próprias" (Baudrillard, 1995, p. 98).

No plano da publicidade e do trabalho ainda existe a segregação do masculino e do feminino. Silva (1998) informa que as mídias criam representações que estão na sociedade, por meio de revistas masculinas e femininas. A autora, ao analisar duas revistas direcionadas para diferentes gêneros, apreende que as mulheres na revista feminina aparecem frágeis, doces, sedutoras, emocionais e privadas; enquanto os homens, na revista masculina, são caracterizados como fortes, bem-sucedidos profissionalmente, racionais, potentes, conquistadores e públicos. As reportagens da revista feminina tratam de assuntos como trabalho, sexo, filhos, corpo, idade, e as da revista masculina abordam temas como aventura, sagacidade e poder.

Em relação à mídia para as mulheres, pode-se observar na pesquisa de Neumann (1998), em páginas econômicas de revistas femininas ou suplementos de grandes jornais, que os artigos tratavam dos assuntos econômicos superficialmente. Ainda para a Neumann (1998, não paginado), "você dá pistas, como que pressupondo que outra pessoa (o homem da casa, talvez) irá completar as informações". As seções econômicas da imprensa feminina são extremamente didáticas, reforçam o consumo, vendendo valores típicos de uma economia globalizada centrada pelo mercado e prevalecendo as funções conotativas (sedução) e emotivas (opinião emitida com objetivo de convencimento). A mulher é percebida como consumidora e não como cidadã, já que não há preocupação em desvendar e explicar, mas apenas em vender, seduzir e iludir. Há ainda a representação clara da visão de usar o homem como referência para definir a competência da mulher, já que as informações sobre o emprego e desemprego feminino usam a realidade masculina como contraponto.

Quando se observam as publicações populares dedicadas à mulher, nota-se, conforme aponta Nunes (2001), que os assuntos são tratados de acordo com os padrões de comportamento vigentes baseados nas trivialidades. O jornalismo para a mulher relaciona-se a assuntos comuns como culinária, decoração, vestuário, família etc, e o sucesso está pautado no sucesso dos outros. A mídia feminina reproduz a imagem da sociedade, como se a mulher não tivesse evoluído e 
conquistado direitos e continuasse a desempenhar as mesmas tarefas domésticas. "Surgem desta forma os comportamentos naturalmente masculinos (força, decisão, racionalidade, liberdade) e os comportamentos femininos (submissão, fragilidade, indecisão, dependência, emocionalidade)" (Silva, 1999, p. 4). O mundo masculino na mídia está configurado no poder, sucesso e prazer, enquanto o da mulher, está voltado a um papel secundário, predominantemente de obrigações.

No caso da mídia de negócios, Cappelle et al. (2003) investigaram duas revistas de gestão, resgatando as relações de gênero com a construção de estereótipos para a mulher e das representações sociais na gerência. Observou-se que a identificação das representações sociais da mulher foi diferenciada por revista: em uma, os preconceitos contra a mulher são percebidos como algo a ser superado; na outra, as representações sociais reproduzem ainda as funções domésticas. As reportagens sugerem uma transição do papel social da mulher, que para Cappelle et al. (2003, p. 15) é justificável já que as representações sociais "[...] são influenciadas pela memória discursiva da sociedade, e portanto, pelos papéis femininos anteriormente representados".

Dentro deste contexto, Cramer, Paula Neto e Silva (2002, p. 28) concordam em que "a representação social funciona como um sistema de interpretação da realidade que regula as relações dos indivíduos com seu meio ambiente físico e social; ela vai orientar seus comportamentos e suas práticas". As autoras discutem gênero como conceito compartilhado pela coletividade, trabalhando o universo simbólico das organizações. Desta forma, engendra-se uma discussão das representações sociais com a cultura que, para Fleury (1996), envolve compartilhamento de significados que manipula o poder dentro da organização. Ao perceber que as relações de gênero fazem parte da dinâmica da realidade social, Cramer, Paula Neto e Silva (2002, p. 29-30) salientam que "[...] a cultura é a base para a percepção de como as representações sociais são construídas e usadas para reforçar e instrumentalizar o poder dentro das organizações".

Tratando-se de uma abordagem mais funcionalista, tenta-se apreender os discursos da alta administração como definidores da realidade organizacional dos seus membros, por meio da manipulação do discurso, com o uso de símbolos, metáforas e imagens, para criar significações e identidade homogêneas na organização (Carrieri, 2001). Na perspectiva de estudar cultura como integracionista, Martin (1992) ressalta a tentativa da alta administração de criar uma única cultura dentro da organização, o que "[...] possibilitaria a visão do quadro ideológico da alta administração que percorre toda a organização" (Carrieri, 2001, p. 31). Neste sentido, Carrieri (2001) ressalta que a cultura é entendida como criada e perpetuada pelos representantes da empresa e vista como variável de manipulação para acordar e clarear valores que mantêm os membros organizacionais unidos e conformados. Assim, nesta 
perspectiva, entende-se que a cultura faz com que os indivíduos percebam por que fazem isso ou aquilo, tendo, desta maneira, os mesmos valores e entendimentos, comprometendo-se com os objetivos da empresa. São várias as formas de integração perpetuadas nas organizações e que podem ser observadas por meio dos jornais internos, relatórios periódicos, documentos, manuais de instrução, comunicados etc (Martin, 1992).

\section{Estratégia Metodológica}

Para possibilitar a investigação das representações sociais de gênero nas organizações, foram analisados jornais de ampla circulação interna de duas indústrias localizadas em Minas Gerais. Garantiu-se às empresas que os dados seriam tratados sem que houvesse a sua identificação, assim serão aqui denominadas de 'Vênus', com mão-de-obra basicamente feminina e 'Marte', com mão-de-obra predominantemente masculina; e os jornais como 'Jornal Vênus' e 'Jornal Marte'.

A Empresa Vênus é uma unidade industrial de uma empresa multinacional de origem francesa que atua no setor de eletroeletrônicos na região Metropolitana de Belo Horizonte. A empresa caracteriza-se pela importação de toda a matériaprima e exportação total do produto final de elevado padrão de desempenho e inovação. De acordo com os dados fornecidos pela empresa, 90\% do operacional da fábrica é composto por mulheres.

A empresa Marte é uma siderúrgica nacional localizada em Minas Gerais, que iniciou as operações na década de 1980, sendo privatizada no início de 1990, após um disputado leilão. Atualmente, a direção da empresa está dividida entre uma grande siderúrgica nacional e o clube de participação acionária dos empregados. A empresa tem seu setor operacional composto, em sua maioria, por homens.

No caso específico desta pesquisa com os jornais internos, pode-se considerála qualitativa de caráter descritivo, porquanto, segundo Bailey (1982), os estudos descritivos objetivam expor um fenômeno em detalhe, especialmente o que está ocorrendo. O método utilizado para a coleta dos dados foi a pesquisa documental em oito jornais da empresa Vênus, veiculados no período de janeiro de 2002 a novembro de 2003 e em sete jornais da empresa Marte, divulgados no período de agosto de 2002 a novembro de 2003.

Para a análise dos jornais foram observados os seguintes tópicos, pautando-se no trabalho realizado por Cappelle et al. (2003).

a) Linha editorial: consiste na forma pela qual os temas são abordados relacionados ao homem e à mulher. 
b) Diagramação e linguagem utilizadas: tais elementos permitem a compreensão do contexto em que determinada representação social aparece, tendo em vista a disposição visual e linguagem do jornal para comunicação com seu público-alvo.

A técnica utilizada para a análise das representações sociais dos elementos acima foi a Análise do Discurso que “[...] visa a articular sua enunciação sobre um certo lugar social. Ela está, portanto, em relação com os gêneros de discurso trabalhados nos setores do espaço social (um café, uma escola, uma loja...) ou nos campos discursivos (político, cientifico...)" (Maingueneau, 2000, p. 13-14, grifos do autor). A Análise do Discurso, como instrumento de identificação das representações, permite investigar, interpretar e analisar a ordem em que aparecem os textos escritos.

Aos pesquisadores coube a identificação de elementos da Análise do Discurso, como os temas recorrentes nos discursos e a utilização de três estratégias de persuasão descritas abaixo, com base em Faria e Linhares (1993).

a.Seleção lexical: a escolha do vocabulário usado no discurso não deve ser percebida como aleatória, pois é relevante recurso argumentativo, delimitando a perspectiva adotada pelo narrador.

b. Construção das personagens: as personagens não são criadas casualmente; encenam conflitos e dão legitimidade e credibilidade às narrativas.

c. Relação entre explícitos e implícitos: os implícitos não constituem o objeto nítido da enunciação, já que, por algum motivo, o narrador não desejou ou não pôde explicitá-los, mas aparecem a partir dos conteúdos explícitos.

Com a estratégia metodológica adotada, foram observados os seguintes temas: assuntos femininos, no Jornal Vênus, assuntos masculinos, no Jornal Marte e os temas relações de poder e competitividade, em ambos os jornais, que foram exemplificados na análise dos dados por fragmentos de texto.

\section{Jornais Internos das empresas Venus e Marte: uma Representação Social de Genero}

\section{Assuntos Femininos}

Ao analisar o Jornal Vênus, constata-se a utilização da cor preta para os textos e da cor rosa para as chamadas, títulos e desenhos caricaturados. A feminilidade do jornal fica indicada na cor rosa e em matérias veiculadas como beleza, culinária, auto-ajuda e questões de interesse feminino, que leva ao tema assuntos femininos 
e às personagens implícitas mãe, dona-de-casa e esposa. A seção Família em Destaque desse jornal aborda assuntos que remetem à vida da mulher, especialmente em família, como amor, afeto, diálogo, cegonha (para conotar gravidez), amamentação, beleza, emagrecimento, climatério, dengue, diversão etc. Como lembram Silva (1999) e Nunes (2001), tais assuntos remetem a um jornalismo tipicamente voltado às mulheres e as "[...] publicações acabam se transformando em um reflexo da vida cotidiana, da economia doméstica, das relações sociais, dos sonhos, dos desejos e das frustrações da mulher contemporânea" (Nunes, 2001, p. 2). Jovchelovitch (1995) e Minayo (1995) acrescentam que as representações individuais refletem o grupo social ao qual o indivíduo pertence, explicando também os interesses específicos de grupos e classes sociais. Os assuntos femininos do Jornal Vênus aparecem na seleção lexical dos fragmentos (1), (2) e (3):

(1) Há vida depois dos 40 (Jornal Vênus, nr. 96, seção Família em Destaque).

(2) Mitos e verdades das receitas de beleza (Jornal Vênus, nr. 92, seção Família em Destaque).

(3) Amor e diálogo no combate às drogas (Jornal Vênus, nr. 93, seção Família em Destaque).

As reportagens veiculadas no Jornal Vênus são didáticas, com desenhos que facilitam o entendimento e, especialmente, apresentam caráter educativo. Percebe-se preocupação nas matérias com a qualidade de vida, retratando assuntos bem próximos da realidade das funcionárias da fábrica e dicas baratas e de fácil acesso. Observam-se, por exemplo, opções de lazer gratuitas 'ou a preços pequenininhos' (Jornal Vênus, nr. 94, seção Família em Destaque) e instruções sobre como obter maiores informações e ajuda gratuitamente, por meio de telefones para contato, endereços e referências de profissionais. Ainda dentro da seção Família em Destaque, encontram-se receitas econômicas e de simples preparo, sugeridas por funcionárias da própria empresa. Entende-se, neste contexto, que a comunicação pode proporcionar diversão e dispor de riqueza de informação (Alexandre, 2001). Mas, também, os assuntos tratados trazem problematizações domésticas para dentro da fábrica, talvez como busca de maior identificação das funcionárias com o ambiente de trabalho, reproduzindo seu papel social pautado na dupla jornada de trabalho (casa e fábrica).

\section{Assuntos Masculinos}

No Jornal Marte, verifica-se a predominância da cor vermelha para títulos e chamadas e a cor preta para os textos. Há neste jornal, muitas fotografias 
coloridas, grande quantidade de textos longos e esquemas. O caráter masculino é ressaltado por meio de matérias direcionadas para negócios, economia, política, controle acionário, poder, sucesso, reforma da previdência, previdência privada, legislação, resultados financeiros e poupança, dentre outros, que remetem ao tema 'assuntos masculinos', indicados nos vocábulos 'fundos de pensão' e 'poupança' dos trechos (4) e (5), respectivamente. Neste caso, percebe-se que os fatos, a diagramação e a linguagem são utilizados de forma que os leitores dos jornais se identifiquem socialmente. As fotografias e os desenhos dos jornais, em sua maioria, são de homens e, quando aparecem mulheres, estão vestidas de 'terninho' ou com o uniforme da empresa, trajes tipicamente masculinos. Tal fato pode ser entendido, quando se percebe que a alta hierarquia da empresa é composta, na maioria, por homens, já que Amorim e Freitas (2003), pontuam que o modelo 'terno e gravata' pode ser adotado por mulheres como, forma de atingir níveis hierárquicos mais elevados.

(4) Na vanguarda dos fundos de pensão (Jornal Marte, nr. 161).

(5) A melhor alternativa de poupança (Jornal Marte, nr. 161).

As análises acima remetem a Silva (1998), compreendendo que os títulos das matérias se direcionam às desigualdades que emergem da sociedade, uma vez que a cultura está presente nos jornais. Pelas marcas lingüísticas dos fragmentos (1) a (5), chega-se ao implícito de que os jornais das empresas Vênus e Marte tentam reproduzir como homens e mulheres devem comportar-se, pensar e viver socialmente. As informações veiculadas estão carregadas de preconceitos que estabelecem os papéis sociais a serem desempenhados por homens e mulheres, reproduzindo os padrões de comportamento preestabelecidos pela sociedade (Silva, 1998).

\section{Relações de Poder}

O primeiro tema que surgiu em ambos os jornais Vênus e Marte é relações de poder Segundo Pontes, Naujorks e Sherer (2001), as informações extraídas das notícias veiculadas nos meios de comunicação permitem contornar os mecanismos utilizados para controle, guardando, entre emissor e receptor, uma relação de poder. No Jornal Vênus, apesar de a empresa ressaltar a importância do trabalho em equipe com a colaboração e 'cooperação de todos' (6), chega-se ao implícito, por meio dos vocábulos sublinhados nos fragmentos (7) e (8), de que há uma tentativa de transferir a responsabilidade dos resultados da empresa às operárias, questionando se estão de fato comprometidas e buscando uma melhoria contínua do trabalho. 
(6) Sem a cooperação de todos, não teríamos cumprido nossos objetivos (Jornal Vênus, nr. 95, seção Especial).

(7) É hora de parar e refletir sobre os motivos que estão levando aos baixos resultados... é hora de reagir (Jornal Vênus, nr. 93, seção Editorial).

(8) E cabe refletir: será que estamos conscientes da importância dos acontecimentos? Estamos agindo com espírito de equipe? Estamos trabalhando em grupo, pensando no objetivo maior que é o de vencer o desafio? (Jornal Vênus, nr. 92, seção Editorial).

Já no Jornal Marte, o discurso da alta administração também pode ser percebido; entretanto não é observada a transferência de responsabilidade dos resultados aos empregados. As relações de poder ficam implícitas em matérias com a mobilização da personagem 'clube de participação acionária dos empregados', que permeiam todos os jornais analisados, como nas marcas lingüísticas dos fragmentos (9) e (10), e em fotografias dos membros organizacionais em todos os jornais, especialmente do presidente do clube, tentando marcar uma posição de poder junto aos empregados. Apesar da ausência da transferência de responsabilidade da alta hierarquia ao empregado, verifica-se uma intenção de transmitir informações positivas sobre a empresa, a fim de que os trabalhadores, que neste caso são também acionistas, se conscientizem das ações e projetos de melhoria que vêm sendo executados pela empresa.

(9) Os 10 anos de vitórias e desafios do clube de participação acionária dos empregados [...] (Jornal Marte, nr. 157).

(10) Como parte das comemorações dos 10 anos do clube..., o [Jornal Marte]... traz mais um depoimento de quem ajudou a construir a trajetória de sucesso do clube [...] (Jornal Marte, nr. 160).

Percebe-se que o discurso da alta administração pode manipular informações dentro da empresa, tentando, por meio dos jornais internos, definir e criar significações e identidades homogêneas entre os grupos para cunhar uma única cultura, conforme a perspectiva de integração, mantendo os membros organizacionais unidos e conformados com os valores perpetuados pela alta hierarquia. Neste sentido, a comunicação serve para difundir essa cultura homogênea, colaborando na formação dos cidadãos e influenciando o comportamento dos indivíduos (Carrieri, 2001; Pontes, Naujorks, \& Sherer, 2001) e, a mídia, aparentemente despretensiosa, interfere e legitima o cotidiano, refletindo os padrões sociais instaurados (Guareschi, 1989; Silva, 1999).

A forma de transmitir esses valores aos seus membros organizacionais, conforme se observa, foi diferenciada nos jornais das empresas Vênus e Marte. Para buscar 
a identificação social, as relações de poder no Jornal Marte indicam a racionalidade e força do homem bem-sucedido, tanto do presidente da empresa, como do presidente do clube de participação acionária dos empregados. Nesse sentido, conforme Silva (1999), os comportamentos masculinos socialmente aceitos estão pautados na força, decisão, racionalidade e liberdade, enquanto os comportamentos femininos estão baseados na submissão, fragilidade, indecisão, dependência e emoção.

Já as relações de poder do Jornal Vênus parecem denotar o caráter submisso, de fragilidade e dependência dos empregados, neste caso, as mulheres, que precisam ser coordenadas para a execução do seu trabalho. De acordo com DaMatta (1991), a mulher tem sempre sua rotina vigiada e controlada pelo homem. Apesar disto, por meio da seleção lexical dos fragmentos (7) e (8), chega-se ao implícito da transferência da culpa às trabalhadoras pelo não cumprimento das metas. Silva (1998) explica que as mulheres ficam sempre indispostas ao sucesso absoluto, sentindo-se culpadas pelo insucesso, fato este justificado pelas imposições culturais. Whitaker (1991) complementa que a culpa faz parte do processo ideológico da mulher, que possui uma vida de culpa ao longo de sua vida adulta: sente-se culpada por abandonar os filhos, quando cometem alguma infração, por não participar do orçamento doméstico, quando o casamento vai mal e quando ganha mais que o marido.

Adicionalmente, é preciso considerar que, conforme aponta Cavedon (2003), as representações sociais remetem aos mitos e ritos, uma vez que as representações têm na fala sua possibilidade maior de revelação. Assim, os mitos e ritos podem ser percebidos como falas dramatizadas que se constituem em elementos reveladores dos significados socialmente construídos e partilhados por grupos sociais. No Jornal Vênus, esse aspecto fica implícito na reportagem do trecho (11), na qual o ex-diretor recebeu homenagens das empregadas pelo desligamento da empresa, após 37 anos, e dramatizou o momento com o plantio de uma roseira no canteiro central da fábrica, marcando-o por meio da comparação explícita dos vocábulos 'roseira' e 'pessoas' (11).

(11) [...] a roseira é como as pessoas: tem que ser cultivada para crescer e florescer (Jornal Vênus, nr. 93, seção Flash).

Percebe-se, pois, que os mitos e ritos trazem à tona as representações sociais de diversos grupos sociais e permitem que as normas, que guiam e controlam os indivíduos, assumam um caráter desejável (Cavedon, 2003). Isto fica notável na empresa Vênus que, ao realizar a 23a edição da Confraternização Pascal, reitera a tradição, fornecendo às operárias um momento de animação e descontração marcado pelas expressões 'relaxar' e 'refletir' (12), que pode permitir a reafirmação de valores da empresa. 
(12) [...] é muito bom! É um momento que dá pra gente relaxar e refletir. Dá vontade de ter duas páscoas por ano, só pra ter duas confraternizações (Jornal Vênus, nr. 97, seção Entre a Gente).

Na empresa Marte, os mitos e ritos também estão presentes nos jornais de circulação interna analisados. Para comemorar o 16o aniversário de operação integrada, a empresa Marte preparou uma exposição de fotos com empregados, que têm filhos com a mesma idade da Empresa: 16 anos. Já para comemorar os 10 anos de 'vitórias e desafios' da personagem 'clube de participação acionária dos empregados', retratado no trecho (9), contratou-se o show de um renomado cantor brasileiro e o evento foi divulgado em uma edição especial do Jornal Marte (nr. 157), intitulada 'Vivendo esse momento lindo', que mostrou fotos dos funcionários com familiares no show e dos preparativos para a festa, enfim os momentos de comemoração muito importante para os funcionários acionistas e, conseqüentemente, para os que ajudaram a construir a história da empresa.

\section{Competitividade}

Outro tema recorrente nos jornais Vênus e Marte é competitividade, que fica implícito em matérias, veiculadas em ambos os jornais, com temas, como: qualidade, redução de custos, diminuição de refugos e atingimento de metas e resultados. $\mathrm{O}$ Jornal Vênus utiliza vocábulos como: PDCA, ferramentas, 5S, Pareto, 'desafios', 'competitivos' e 'melhoria contínua' (13); e o Jornal Marte, ISO, riscos ambientais, gestão da qualidade, melhoria contínua, satisfação do cliente, bem como os sublinhados no fragmento (14).

(13) [...] a fórmula para superarmos os desafios e nos mantermos competitivos, pode ser traduzida em duas palavras: melhoria contínua (Jornal Vênus, nr. 99, seção Editorial).

(14) [...] o técnico da seleção brasileira, Carlos Alberto Parreira, conversará com os empregados... sobre planejamento, estratégia, metas e motivação, ferramentas necessárias para o alcance dos objetivos pretendidos (Jornal Marte, nr. 162).

No entanto, apesar de o tema 'competitividade' aparecer em ambos jornais, o enfoque pareceu ser diferenciado. No Jornal Vênus, a competitividade foi vinculada ao atingimento de metas da empresa, ou seja, os empregados passam a ser responsáveis pelo resultado, uma vez que a empresa é entendida como um grande grupo, o que fica implícito quando é mobilizada a personagem 'nós', sujeito gramatical dos verbos 'superarmos' e 'mantermos' (13). Quando a alta hierarquia coloca metas e demanda das operárias uma maior produtividade e qualidade, o 
Jornal Vênus faz menção da importância do posicionamento da fábrica dentro do grupo estrangeiro. Observa-se, então, que existe concorrência interna entre as fábricas localizadas nos diversos países, que precisam ser competitivas e ter resultado financeiro positivo para que a matriz não encerre a operação da filial local, o que fica implícito nas marcas textuais 'merecedores' e 'confiança' (15) e 'concorrente' (16). Neste cenário, a alta hierarquia transfere a responsabilidade da continuidade da fábrica e, conseqüentemente, da manutenção dos empregos para as próprias operárias.

(15) [A empresa] vive um momento muito positivo, causado pelo aumento considerável de produção, em função do fechamento da unidade do México... Mas é também um momento delicado. Temos que mostrar que somos merecedores de tamanha confiança (Jornal Vênus, nr. 92, seção Editorial).

(16) Assim é a fábrica da Polônia, cliente e também concorrente da fábrica de Belo Horizonte [...] (Jornal Vênus, nr. 98, seção Especial).

Em contrapartida, no Jornal Marte, o tema competitividade foi relacionado ao indivíduo, indicando concorrência entre grupos ou, até mesmo, entre indivíduos. Diferentemente do Jornal Vênus, conforme exemplificado na expressão negritada 'conversará com os empregados', do fragmento (14), chega-se ao implícito de que a alta hierarquia se excluiu do grupo de empregados. As competições internas entre equipes de trabalho e que são estimuladas pela empresa são retratadas ao longo dos jornais analisados. Esse estímulo competitivo reforça a idéia de sucesso, que pode ser explicado, quando se observa que o homem não tolera nenhum fracasso (Baudrillard, 1995). Conforme se evidencia na matéria intitulada 'Só a vitória interessa, de novo!' (Jornal Marte, nr. 159), o mundo masculino está configurado no poder, sucesso e prazer, enquanto o da mulher está voltado a um papel secundário, predominantemente de obrigações sociais (Silva, 1999).

Diante das análises realizadas, observou-se, na empresa Vênus, a utilização dos jornais internos para transmitir a importância do empregado à empresa, o que leva à personagem 'mãe', mas tem-se, implicitamente, uma tentativa de cooptação das operárias para aumentar o comprometimento e gerar resultados positivos à empresa. Já no Jornal Marte se verifica a empresa vinculada à personagem 'pai', provedor, aquele que cuida e fornece os recursos necessários, tanto de qualidade de vida como financeiros aos empregados e à comunidade. Ao contextualizar a empresa Marte e entender como ocorre a interação dos diversos atores sociais, chega-se ao implícito da disputa de poder entre os acionistas, o clube de participação acionária dos empregados, representado pela personagem 'diretor' da empresa e o acionista majoritário, representado pela personagem 'presidente' da empresa, fato que permeia todos os jornais analisados da empresa Marte. 
Desta forma, ratifica-se o pensamento de Pontes, Naujorks e Sherer (2001), segundo o qual a comunicação é um processo complexo que abrange também as relações de poder com mecanismos de controle, de formação de sujeitos e produção de sentidos; são processos de argumentação, subjetivação e construção da realidade.

\section{Considerações Finais}

A análise dos jornais das empresas Vênus e Marte possibilitou verificar a tentativa de utilização de temas femininos e masculinos, para que o público-alvo se identificasse com os assuntos que, na realidade, são reproduções das representações sociais. Adicionalmente foi também constatada a utilização de rituais que, conforme afirma Cavedon (2003), permite que as emoções, os sentimentos, os medos, ódios, amores e crenças dos homens se manifestem. É neste momento que regras, normas, relações de poder e valores sociais se materializam e se legitimam, refletindo a realidade do grupo, da comunidade ou de uma sociedade.

Notou-se que os jornais das duas empresas disseminaram idéias de como homens e mulheres se devem comportar, pensar e viver socialmente. Reitera-se, pois, por meio da pesquisa realizada no Jornal Vênus, o que Nunes (2001) havia constatado: as publicações de expressão popular, dirigidas ao público feminino, acabam transformando-se em um reflexo da vida cotidiana, da economia doméstica, das relações sociais, dos sonhos, dos desejos e das frustrações das mulheres contemporâneas. Por outro lado, no Jornal Marte, reproduz-se o papel dos homens na sociedade como indivíduos racionais e potentes, com o comportamento pautado na energia e competitividade, verificando-se um complexo jogo de poder como modelo socialmente construído e aceito (Meyer, 1998; Silva, 1998).

Entretanto percebe-se que as reproduções das representações sociais são carregadas de preconceitos que delimitam os papéis sociais de homens e mulheres, reproduzindo os padrões de comportamento preestabelecidos pela sociedade. Constatou-se, por meio da análise dos jornais, que a mulher tem acumulado funções na atualidade: mãe, esposa, amante e profissional. Apesar da suposta 'ampliação' do papel do homem na sociedade, o que se percebeu é que continua sendo o provedor, o responsável pelo dinheiro, pelo poder e não foi identificado o papel de 'cozinheiro' ou 'dono-de-casa' nos jornais analisados da empresa Marte. Essa diferença de atribuições, ou seja, as mulheres acumulando funções enquanto os homens continuam com os mesmos papéis, pode ser entendida, quando se verifica que o momento atual é de transição e as representações são influenciadas pela memória remanescente da sociedade. 
Mesmo sendo as informações carregadas de preconceito, apreendeu-se que é por meio da identificação do público-alvo com os assuntos apresentados que as resistências individuais podem ter sido minimizadas, acarretando maior controle psicológico e permitindo a transmissão mais fácil de assuntos delicados. Além disso, a análise realizada indicou que as palavras e imagens veiculadas periodicamente podem ter servido como pano de fundo para difundir o poder da alta administração sobre os leitores dos jornais. A mídia, neste caso os jornais internos das duas empresas, constituiu-se em fonte de perpetuação do poder da alta administração e de manipulação e controle de comportamentos, cujos conteúdos são explicitados intencionalmente, visando à normatização e legitimação de certos procedimentos dentro da organização.

As representações sociais existem e reproduzem aspectos que são construídos ao longo do tempo. É por esta razão que se deve analisar cuidadosamente os meios de comunicação, para que aspectos que passariam despercebidos possam ser constatados, a fim de se ter melhor compreensão da reprodução da realidade, e em específico, neste caso, daquela realidade voltada às questões de gênero.

Esta pesquisa buscou trazer uma contribuição para os estudos organizacionais, já que permitiu análise teórica e investigação e reflexão de fenômenos que influenciam as interações dos atores na dinâmica e nos resultados da organização. Desta forma, verificou-se como o discurso da alta administração, realizado por meios de comunicação, pode ser utilizado para a perpetuação das relações construídas socialmente, que acabam por pactuar com as desigualdades de gênero e de poder, além de 'fechar os olhos' para a evolução cultural e histórica entre os universos masculino e feminino.

\section{Artigo recebido em 14.10.2004. Aprovado em 05.05.2005.}

\section{Nota}

${ }^{1}$ Durkheim, E. (1978). Os pensadores. São Paulo: Abril Cultural.

\section{ReferénCIAS Bibliográficas}

Adorno, T. W. (1975).

A indústria cultural. In G. Cohn (Org). Comunicação e indústria cultural: leituras de análise dos meios de comunicação na sociedade contemporânea e das manifestações da opinião pública, propaganda $e$ cultura de massa nessa sociedade. São Paulo: Nacional. 
Alexandre, M. (2001, julho/dezembro). O papel da mídia na difusão das representações sociais. Comum. 6(17), 111-125.

Amorim, T. N. G. F., \&

Freitas, T. S. (2003).

Terninho e gravata... Opção ou obrigação para as executivas? Anais do Encontro Nacional dos Programas de Pós-Graduação em Administração, Atibaia, SP, Brasil, 27.

Bailey, K. D. (1982).

Methods of social research (2nd ed.). New York: The Free Press.

Baudrillard, J. (1995).

A sociedade de consumo. Rio de Janeiro: Elfos.

Cappelle, M. C.A.,

Mageste, G. S. de,

Melo, M. C. O. L. de, \&

Brito, M. J. M. (2003).

A representação feminina na mídia de negócios: um Estudo com duas revistas populares especializadas em gestão. Anais do Encontro Nacional dos Programas de Pós-Graduação em Administração, Atibaia, SP, Brasil, 27.

Carrieri, A. de P. (2001).

O fim do "mundo telemig": a transformação das significações culturais em uma empresa de telecomunicações. Tese de Doutorado, Universidade Federal de Minas Gerais, Belo Horizonte, MG, Brasil.

Cramer,L.,

Paula Neto, A. de, \&

Silva, A. L. (2002, maio/agosto).

A inserção do feminino no universo masculino: representações da educação superior. Organizações \& Sociedade, 9(24), 25-37.

Cavedon, N. R. (2003).

Antropologia para administradores. Porto Alegre: Editora da UFRGS.

Damatta, R. (1991).

A casa \& a rua: espaço, cidadania, mulher e morte no Brasil (4th ed.). Rio de Janeiro: Guanabara Koogan.

Faria, A. A. M. de, \&

Linhares, P. T. F. S. (1993).

O preço da passagem no discurso de uma empresa de ônibus. Cadernos de Pesquisa do NAPQ, 13, 32-38.

Fleury, M. T. L. (1996).

O desvendar a cultura de uma organização: uma discussão metodológica. In M. T. L. Fleury \& R. M. Fischer (Coord.). Cultura e poder nas organizações (2nd ed.). São Paulo: Atlas.

Guareschi, P. (1989, setembro).

A cozinha da ideologia dominante. Revista Mundo Jovem, (153).

Hall, S. (2002).

A identidade cultural na pósmodernidade. Rio de Janeiro: DP\&A.

Jovchelovitch, S. (1995).

Vivendo a vida com os outros: intersubjetividade, espaço público e representações sociais. In P. Guareschi \& S. Jovchelovitch (Orgs). Textos em representações sociais (2nd ed., pp. 63-85). Petrópolis, RJ: Vozes. 
Magnani, J. G. C. (1986).

Discurso e representação ou de como os baloma de Kiriwana podem reencarnar-se nas atuais pesquisas. In R. Cardoso (Org.). A aventura antropológica (pp. 127-140). Rio de Janeiro: Paz e Terra.

Maingueneau, D. (2000).

Termos-chave da analise do discurso. Belo Horizonte: Editora UFMG

Martin, J. (1992).

Cultures in organizations - three perspectives. Oxford: Oxford University Press.

Meyer, D. E. E. (1998, junho).

A dúvida como postura intelectual: uma abordagem pós-estruturalista dos estudos de gênero na enfermagem. Nursing Edição Brasileira, 1(1), 27-34.

Minayo, M. C. S. de (1995).

$\mathrm{O}$ conceito de representações sociais dentro da sociologia clássica. In P. Guareschi \& S. Jovchelovitch (Orgs). Textos em representações sociais. (2nd ed., pp. 89-111). Petrópolis, RJ: Vozes.

Moscovici, S. (1978).

A representação social da psicanálise. Rio de Janeiro: Zahar.

Neumann, D. M. (1998).

Jornalismo econômico na imprensa feminina. Anais do Congresso Brasileiro da Comunicação, Recife, PE, Brasil, 21.
Nunes, A. M. (2001).

Uma história mal contada: a imagem da mulher nas populares. Anais do Congresso Brasileiro da Comunicação, Campo Grande, MS, Brasil, 24.

Pontes, B. S.,

Naujorks, M. I., \&

Sherer, A. (2001)

Mídia impressa, discurso e representação social: a constituição do sujeito deficiente. Anais do Congresso Brasileiro da Comunicação, Campo Grande, MS, Brasil, 24.

Silva, M.L. (1998).

Playboy / Claudia: os universos discursivos e a construção de imagens de homens e mulheres. Anais do Congresso Brasileiro da Comunicação, Recife, PE, Brasil, 21.

Silva, M. L. (1999).

Revista Íntima, permitida para mulheres. Anais do Congresso Brasileiro da Comunicação, Rio de Janeiro, RJ, Brasil, 22.

Thompson, J. B. (1995).

Ideologia e cultura moderna. Petrópolis: Vozes.

Whitaker, D. (1991).

Mulher e homem: o mito das desigualdades. São Paulo: Moderna.

Wood, T., Jr., \&

Paula, A. P. P. (2002).

Pop-management: pesquisa sobre as revistas populares de gestão no Brasil. Anais do Congresso Brasileiro da Comunicação, Salvador, BA, Brasil, 26. 